\title{
THE USE OF DESCRIBING PICTURE STRATEGY TO IMPROVE SECONDARY STUDENTS' SPEAKING SKILL
}

\author{
Zakiyah Farhanah Pratiwi', Mutiara Ayu ${ }^{2}$ \\ Universitas Pendidikan Indonesia ${ }^{1,2}$
}

zakiyahfp@gmail.com ${ }^{1}$, mutiara.ayu @ teknokrat.ac.id $^{2}$

\begin{abstract}
Received: 13 October 2020
Accepted: 8 December 2020

Abstract

Describing picture strategy is one of the techniques that can be used to improve students' speaking skills. Speaking skill is one of the subjects that difficult to be mastered by young learners. This study was conducted in SMA Al Azhar 3 Bandar Lampung at first-grade students. With qualitative data, the result showed that describing a picture strategy can improve students' speaking skills. This finding is in line with the previous research finding that describing pictures can help students to improve students' speaking skills. Nevertheless, there are some problems gained in using describing picture strategy. Many students could not apply grammar correctly when they speak by using the strategy. The students are difficult to understand English when their friends speak English using describing the picture.
\end{abstract}

Published: 30 December 2020

Keywords: Describing Picture Strategy, Speaking Skill

\section{To cite this article:}

Pratiwi, Z. F. \& Ayu, M. (2020). The Use of Describing Picture Strategy to Improve Secondary Students' Speaking Skill. Journal of English Language Teaching and Learning, 1(2), 38-43.

\section{INTRODUCTION}

The background of this study is an effort to know which technique is suitable to use in teaching speaking. Teaching a foreign language is considered to be one of the most challenging teaching practices. It is in line with Oktaviani (2016) that the speaking skills of EFL students are influenced by some factors. In Indonesia, students are usually afraid of joining foreign language classes. They may feel unmotivated, discouraged easily. Their mindsets say foreign language is difficult to learn because most of them know nothing from the start. Usually, students know nothing about how to express what they want to say. Students who have learned English for several years have not been can communicate using English. Their mindsets say foreign language is difficult to learn because most of them know nothing from the start. Having learned English for more than 6 years did not change their mind that learning English should be fun. On the other hand, learning English through the textbook did not help students to improve their English ability. This condition was getting worse when students had to pass their minimum passing grade. But usually, students know nothing about how to express what they want to say. The reasons for learning are to change students' intellectuality, morality, and societal attitude. To reach the reason, the students interact with the circle of learning that arranged by the teacher in the learning process. There are two aspects in learning methodology such as; the learning method and learning media as tools to help students in the learning process. While, judgment is a tool to measure or determine the standard of achievement on the reason of learning (Sudjana \& Rivai, 2001). Learning media in the learning process gives advantages to make learning more attractive, the material of learning more clearly, learning methods more have variation. Using media in teaching can improve students' motivation in learning English (Oktaviani \& Mandasari, 2020). The researcher chooses to describe the picture to teach speaking in descriptive text because by describing pictures the students will be easier to express their ideas. With the describing picture, they can reflect on the image, when they see it. So if they can express their ideas of course they will speak and the teacher can know the purpose of student's mean.

The success of the teaching-learning process is highly influenced by the patterns of interactions that appeared in classroom activities (Sari, 2018). There is an alternative for teachers to make the class interesting by using a learning application since it is also a trigger for students to learn in a very attractive way and boost their English skills without having a monotonous activity in a class (Wahyudin \& Rido, 2020). Describing pictures is one of the activities in learning to speak English. In this activity, students must describe pictures in front of the class. Every student gets one picture and must describe it. The purposes of this activity are to train students' 
imagination and retell stories in speaking English. (Solahudin, 2009). While the descriptive text is a genre that has a social function to describe a particular person, place, or thing (Gerot \& Wignel, 1998). Based on the studies that had been stated above, the use of pictures is important because it may give a significant impact on the teachinglearning process, especially in teaching English skills that had been conducted in some schools. The use of pictures may also create an interesting situation in the classroom. Because of that, the researcher was interested to conduct classroom action research to improves students' speaking ability by describing pictures.

To aid teachers in conducting instructions and achieving the objectives of materials, they can use some instructional materials as the source of teaching and learning activities in the classroom (Ayu \& Indrawati, 2018). Many techniques can be applied to teach students English speaking. Using interesting material, media, and techniques in teaching English is the first thing that can motivate the students to learn English. One of the techniques is describing pictures. The writer chooses the describing pictures for this study because pictures are good visual aid in teaching-learning in the classroom and considered effectively to engage the students" attention. According to Huebner (1990), picture as one of the visual aids is every type of pictorial presentation. Pictures can be designed and be used in teaching material in expressing personal identity text. The media will facilitate the capture of student or teacher to master the material presented.

Moreover, the students can practice their speaking fluently by using correct pronunciation in explaining the content of pictures in front of the class. The learning process truly depends on the teachers on how they guide the students and create the teaching-learning process become comfortable. It can be applied through the use of pictures. To actualize an effective process of learning, the writer conducts a study to improve students ${ }^{\text {ee }}$ speaking. The use of describing picture strategy is one of the alternative techniques that can be used in. In this study, the writer would like to find out how describing picture could help the teacher constructs the lively teaching-learning process and could improve students' English speaking skill in senior high school.

\section{LITERATURE REVIEW Definition of Speaking}

There are many definitions of speaking according to some experts. Harmer (2007) states that speaking is the ability to speak fluently and presupposes not only knowledge of language features, but also the ability to process information and language on the spot while Quianthy (1990) defines speaking as the process of transmitting ideas and information orally in a variety of situations. Speaking is the use of language quickly and confidently with few unnatural pauses, which is called fluency. Speaking is the process of building and sharing meaning through the use of verbal and nonverbal symbols, in a variety of contexts. (Chaney, 1998). Speaking in a second or foreign language has often been viewed as the most demanding of the four skills. When attempting to speak, learners must muster their thoughts and encode those ideas in the vocabulary and syntactic structures of the target language. Therefore, the researcher concludes that speaking is the ability to produce the language and share their ideas.

\section{Teaching Speaking}

The teaching and learning process of English in Senior High School is based on the school-based curriculum. The latest approach stressed that language is acquired through communication. The basic language assumptions are: (a) Language as a means of communication is used to express meaning grammatically; and (b) Learning a foreign language is how to communicate using that language itself as a target language, written or orally. They are supported by the elements of the target language. Speaking is an interactive task and it happens under real-time processing constraints. It means that they will be able to use words and phrases fluently without very much conscious thought. Effective speakers need to be able to process language in their heads and put it into coherent order so that it comes out in forms that are not only comprehensible but also convey the meaning and contexts that are intended. (Harmer, 2001). In the current curriculum '2013 Curriculum' employed by Indonesian education, it is stated that the materials in the activities should be designed interactively based on the students' background knowledge, the place where they live, the food they eat, the buildings and tourisms around them, customs and moral values in existence to make their national (Ayu, 2020). One of the reasons for including speaking activities in language lessons is to help students familiar with the oral use of language in English conversation. Speaking activities provide exercise opportunities in real-life speaking in the safety classroom.

\section{Models of Teaching Speaking}

The average person who wants to learn the English language, most certainly they have the same reason. It is can speak English. So, they learn the English language to try speaking English. Usually, failure of learning speaking causes bore situation in the class, unattractive, less fun, and silence in the class. There are many media of learning speaking. Using teaching media in teaching gives some benefits that can cope with the students' characteristics (Wahyudin, 2017). According to Solahudin (2009), there are some models of learning speaking as follows: 
a. Main class and study club

It is better for meeting with the teacher in the class twice a day. The first meeting is called the main class and the second meeting is called a study club. The main class is meeting with the teacher, that the teacher as students' advisor in the class. The teacher has an important character in the class. All activities in the class depending on the teacher. Study club is a group of learning, it held to repeat the material study in the class by senior. Because the senior is not a teacher, so the students more enjoy make questions and practices speaking with the senior. Activities in the study club are not different from the main class, because the reason for the study is to explain material learning (Solahudin, 2009).

b. Conversation on the way

Conversation on the way is one of the activities in speaking class. The function is to bore disappear in the class. They can share their daily activity. So, the students feel the conversation more clearly, attractive, and comfortable

c. Discussion group

A discussion group is one of the activities in speaking class. Discussion in speaking's the program only talking about an easy topic. Because this discussion just to train the students to speak English. The purpose of the discussion is to train the students to speak English more clearly

d. Describing picture

Describing pictures is one of the activities in teaching speaking English. In this activity, students must describe pictures in front of the class. Every student gets one picture and must describe it. The purposes of this activity are to train students' imagination and retell the story in speaking English. Students stated that they can overcome the constraints in the learning process of speaking activity through sharing in front of the class. It is in line with the findings of research conducted by Apriyanti \& Ayu (2020) that the sharing technique is one of the cooperative learning strategies that promote student involvement in the classroom. Those are models that Solahudin offers to use in speaking class, and as the title of this research, the researcher chooses the last model. The researcher thinks that describing picture is suitable to improve students' speaking skill in descriptive text because the purposes of these activities are to train students' imagination and describe something in speaking English. Usually, students can not speak anything because they have not an idea. The researcher hopes that pictures can help students to speak English because students will be easier to say when they see them. The writer will make this activity more attractive and make students get enjoyment in the class.

\section{The Procedures of Describing Method}

Describing the picture is a method that is very easy to play. The study can be maximum if the students use the five senses because they can be attractive to express something with their five senses. The five senses used by the students in describing the picture; they used eyes to saw the picture, used ears to listen to what their partner said, used mouth to describe the picture. Aminatun and Oktaviani (2019) said that applying language learning applications in an English class can build the students learning autonomous skills and interestingly support their independent learning. Therefore, the writer hopes with using the describing picture, students can be more active in the class and improve their speaking skills. There are steps of application in describing picture according to Ismail (2008) as follows:

1. The teacher prepares a picture according to the topic or material of the subject.

2. The teacher asks students to examine the picture accuracy.

3. The teacher divides students into groups.

4. The teacher asks all members of groups to write the vocabularies based on the result of their examined the picture

5. Then, every group makes sentences and writes on the blackboard.

6. After that, every group describes their picture by speaking in front of the Class.

7. Clarification/ conclusion/ teacher reflection.

To be a success in teaching by using describing picture strategy, some preparations and procedure are needed to give regulations to the students, so that the students can understand the activityes rule. Preparations and procedures that are used in describing the picture as follows:

1. Preparation

The writer must prepare material that is used in describing the picture strategy. The preparations are: select the material from magazines, the internet, books, any pictures which show several different objects, the objects should be clear in shape. It is amusing if the objects are bizarre in some ways (Wright, 1983).

2. Procedures 
There are some procedures of describing the picture to teach speaking especially in descriptive text, they are:

a. Let the class work in pairs.

b. Give each pair two different pictures. Tell them not to look at each other pictures.

c. Ask A to describe his or her picture and ask B to draw it. Ask B to do the same as what A does after B has finished drawing.

d. Ask them to compare their picture with the original (Wright, 1983).

These preparations and procedures of describing pictures can create students being more active and there is no boredom in the class. Based on the preparation and procedures, describing the picture is one of the useful and successful strategies for improving students' speaking. Then, this practice of speaking can lead to meaningful communication than only memorizing (Wahyudin, 2017).

\section{METHOD}

This research was conducted at one of the Senior High Schools in Bandar Lampung. The treatment was carried out 5 times face to face. This research method is a qualitative type of embedded single case study. Data sources include (1) informants, namely teachers and students, (2) Pre Test and Post Test methods compiled by the teacher.

\section{FINDINGS AND DISCUSSION}

Based on the results of observations of learning in the field and analysis of the learning process plan documents, the use of describing pictures in the first year of SMA Al Azhar Bandar Lampung ran well and interactively. Learning indicators developed include (1) Being able to describe something, (2) Being confident to speak English, and (3) Being able to speak fluently. The materials presented in learning were how to describing something by seeing the picture, various pictures to supporting the material. The use of describing picture strategy in the learning plan created by the teacher was applied in three meetings. Each meeting took 45 minutes. The objectives achieved in the first meeting were (1) students could describe the picture. Learning objectives to be achieved at the second meeting (2) was that students could describe many pictures fluently. Then in the third meeting was the students could describe anything without a picture fluently.

Each meeting specifically used two procedures. The first procedure is the pre-test. Before the teacher starts the material, the teacher gives students some objects to described but without the picture. Then, students were thinking about the object that must be described individually. They would start to describe the object using their own words and do it as best as they can. They can try it in front of the class to make them feel confident when they speak English and the other students listen to their friends. In Pre-test, the score shows that $80 \%$ of students can show their improvement in answering the questions. The pre-test with 2 trials that the first one with no picture and the second one with a picture, then from these trial show that students had improvement in their speaking ability, they feel confident when they describe the picture. They know what should they speak with the picture, so they do not feel confused.

The second procedure is post-test. The teacher does the post-test at the end of the class session. This procedure to see the result by using a picture in describing something. According to Hamalik (1988), pictures are effective visual media that are very important and easy. They can facilitate students to catch the ideas. The teacher chooses the object that matches with the material in the meetings and students to try to answer it individually. The Post-test score shows the same percentage as the pre-test score that students can improve their speaking ability when using a describing picture. The data from the interview, observation, diary notes, and documentation also showed the students' improvement in describing pictures strategy. All of these data were indicated the students gave a good attitude and response during the teaching-learning process. The students were also more interested in describing the picture strategy.

Stages that match the general stages of the learning technique are used to implement descriptive text learning using photos in the lesson plans that were directly developed by the instructor. It does not, in other words, go out of the norm in theoretical phases. During the descriptive text learning process, the phases of the learning scenario specified in the learning process plan were carried out coherently by the teacher, while the instructor often improvises according to the circumstance and learning circumstances, it does not preclude it.

In the learning process of descriptive text in the third meeting, the teacher applied the question in a group. So each student in the group must describe anything about the object and another member could not say the same as their friends. Burn $(1975$, p.11) states that pictures will help us to initiate a new topic or catch studente"s interest as they look and talk about them. So the teacher must make sure that the picture is related to the topic and can be answered by all the students. Further, in this session, students can improve their speaking skills because they will try to find other words and say them loudly.

As a result, the use of describing picture strategy in the descriptive text was pretty good. This is supported by Asfa (2010) as a student of English Language Education at the Walisongo State Institute for Islamic Studies, 
Khamsiah (2016) as a student of English Language Education at Pasir Pengaraian University, Karsono (2014) as an instructor of SMPN 1 Anggana, and Wulandari (2012) as a student of the Department of English Education at Yogyakarta State University. They said that describing pictures was an important technique for improving the ability of students to speak because the picture media helps students develop their ability to speak. They became easy to speak by using the technique so that they could boost their fluency, material, pronunciation, and grammar. Then from Lubis (2017) said that there was an improvement in the students' speaking ability at describing pictures strategy of the picture as media. It was proved by the data; the students' score in pre-test and the lowest score of post-test is 60 , it means that describing picture help students in speaking ability because in using the picture, students will try to speak what do they know about the picture, so there is a curiosity in students themselves to speak something because the picture can attract students to say something about what they see. Describing the picture strategy was enough to contribute to the learning process. A method, both teachers and students, particularly for enhancing student speaking skills. Teachers are assisted in different ways by using this approach, including ease of preparation and implementing methods.

In improving students' speaking skills, the activities during the learning process must be related to that. As we know, speaking skill is one of the skills that difficult to be mastered by young learners. With this strategy, the writer found the differences in students when they describing something with the picture. They can speak confidently in front of the class and they try to say something because they think about the picture. According to Solahudin (2009), describing pictures is useful for training students ${ }^{\text {ee }}$ imagination and retell the story in English speaking. As the researcher said before that the picture can attract students to say something about what they see in the picture, even it is not related to teacher questions' but they feel confident to describe the picture.

\section{CONCLUSION}

The use of describing picture strategy improves students' English-speaking competence. This can be known by the cumulative pre-test and post-test scores. There was a major gap in the pre-test and post-test rankings. Besides, the effect of explaining the image strategy is not only accomplished by the achievement of the students but also obtained by questionnaire responses from the students. The outcome indicated that the students were involved in the technique. However, in this strategy students could not use their grammar well. Because they speak constantly when seeing the picture, they are not aware of the grammar. But as a teacher should try hard to encourage the students to reach the purpose of English learning, especially in speaking.

\section{REFERENCES}

Aminatun, D., \& Oktaviani, L. (2019). Memrise: Promoting Students' Autonomous Learning Skills through Language Learning Application. Metathesis: Journal of English Language, Literature, and Teaching, 3(2), 214-224.

Apriyanti, D., \& Ayu, M. (2020). Think-Pair-Share: Engaging Students in Speaking Activities in Classroom. Journal of English Language Teaching and Learning, 1(1), 13-19.

Asfa, I.A. (2010). The Effectiveness of Using Describing Picture to Improve Students Speaking Skill in Descriptive Text. Semarang: Walisongo State Institute for Islamic studies.

Ayu, M. (2020). Evaluation of Cultural Content on English Textbook Used by EFL Students in Indonesia. Journal of English Teaching, 6(3), 183-192.

Ayu, M., \& Indrawati, R. (2018). EFL Textbook Evaluation: The Analysis of Tasks Presented in English Textbook. Teknosastik, 16(1), 21-25.

Burns, C. P. 1975. The Language Arts in Childhood Education. Chicago: Rand Mc Nally.

Chaney, A. L., \& Burke, T. L. (1998). Teaching Oral Communication in Grade K-8. Boston: Allyn \& Bacon.

Gerot, L., \& Wignell, P. (1994). Making Sense of Functional Grammar. Sydney: Antipodean Educational Enterprise.

Hamalik, O. (1988). Media Pendidikan. Bandung: Pt. Alumni.

Harmer, J. (2001). The Practice of English Language Teaching. Great Britain: Pearson Education.

Harmer, J. (2007). The Practice of English Language Teaching. London: Longman Group.

Huebner, E., S. (1991). The Generalizability of the Confirmation Bias among School Psychologists. SAGEJournals, 11(4).

Ismail, S. M. (2008). Strategi Pembelajaran Agama Islam Bebasis Paikem. Semarang: RaSAIL Media Group.

Karsono. (2014). Improvement of Speaking Ability in Using Describing Picture Strategy. Malang.

Khamsiah. (2016). Improving Studentsee Speaking in Expressing Personal Identity Through Picture Media at Grade VII-A SMPN 1 Tandun. Journal Mahasiswa FKIP Universitas Pasir Pengaraian. 2(2). 1-10.

Lubis, M. W. (2017). The implementation of describing pictures strategy in improving students' speaking ability at MTS Yayasan madrasah Islamiyah Medan. Medan: The State Islamic University of North Sumatera.

Oktaviani, L. (2016). Studi Tentang Faktor yang Mempengaruhi Kemampuan Berbicara Jurusan Bahasa Inggris di Universitas Muhammadiyah Malang. In Tursini, U. et al. (Eds.), Seminar Nasional: Paper was presented in Membangun Karakter Dosen sebagai Peneliti dan Pengabdi dalam Memasuki Persaingan Global: Prosiding Seminar Nasional Hasil Penelitian (pp. 342-246). Malang: LPPM Universitas Kanjuruhan Malang.

Oktaviani, L. \& Mandasari, B. (2020). Powtoon: A Digital Medium to Optimize Students' Cultural Presentation in ELT Classroom. Teknosastik: Jurnal Bahasa dan Sastra, 18(1), 33-41. 
Quianthy, R.L. (1990). Communication is life: Essential college sophomore speaking and listening competencies. Annandale, VA: National Communication Association

Sari, F. M. (2018). Patterns of Teaching-Learning Interaction in the EFL Classroom. Teknosastik: Jurnal Bahasa dan Sastra, $16(2), 41-48$.

Solahudin, M. (2009). Kiat-Kiat Praktis Belajar Speaking. Jogjakarta: Diva Press.

Sudjana, N., \& Rivai, A. (2001). Media Pengajaran. Bandung: Sinar Baru Algesindo.

Wahyudin, A. Y. (2017). The Effect of Project-Based Learning on L2 Spoken Performance of Undergraduate Students in English for Business Class. Paper presented on The Ninth International Conference on Applied Linguistics (Conaplin 9), 42-46.

Wahyudin, A. Y. \& Rido. A. (2020). Perceptuals learning styles preferences of international master's students in Malaysia. BAHTERA: Jurnal Pendidikan Bahasa Dan Sastra, 19(1), 95-103.

Wulandari, R. (2012). The Use of Pictures to Improve The Students' Speaking ability of XI IS 2 of SMAN 1 Kasihan. Yogyakarta: Universitas Negeri Yogyakarta.

Wright, A. (1983). Games for Language Learning. Australia: Cambridge University Press.

\section{BIOGRAPHY OF AUTHORS}

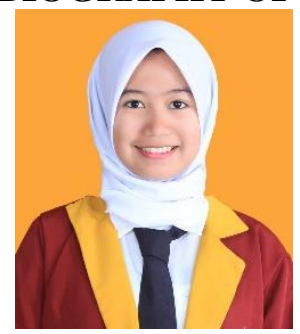

Zakiyah Farhanah Pratiwi is a college student from the English Education study program, Faculty of Arts and Education, Universitas Teknokrat Indonesia. Her interest is in teaching English to young learners. She is also a preschool teacher at Wellington School. She likes to speak English and now she can use it when she is teaching because the school uses English for the main language instruction.

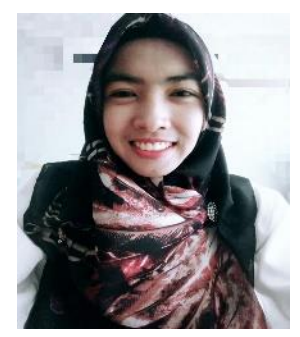

Mutiara Ayu is an English Education Lecturer in Universitas Teknokrat Indonesia. She actively participates as a presenter at national and international conferences and publishes her studies in some journals. Her research interest is English teaching and learning, teaching strategies, textbook evaluation, and TEYL. 